\title{
Enablers to Information Search and Use in Higher Learning
}

\author{
Aidah A. Karim, Fariza Khalid, M. Khalid M. Nasir, Siti Mistima Maat, M. Yusoff Daud, \\ Shahlan Surat
}

Faculty of Education, Universiti Kebangsaan Malaysia, UKM Bangi, Selangor, Malaysia

Email: eda@ukm.edu.my

How to cite this paper: Karim, A. A., Khalid, F., Nasir, M. K. M., Maat, S. M., Daud, M. Y., \& Surat, S. (2018). Enablers to Information Search and Use in Higher Learning. Creative Education, 9, 2089-2100. https://doi.org/10.4236/ce.2018.914151

Received: August 16, 2018

Accepted: October 23, 2018

Published: October 26, 2018

Copyright (c) 2018 by authors and Scientific Research Publishing Inc. This work is licensed under the Creative Commons Attribution International License (CC BY 4.0).

http://creativecommons.org/licenses/by/4.0/

\section{cc) (†) Open Access}

\begin{abstract}
Information search and use hold a key to knowledge building process in higher learning. A qualitative study was conducted to explore the role of various personal skills that empower students' information search and use in higher learning. The study involved 30 lecturers, librarians and students who participated in student information skills programs run by a public university library in Malaysia. The study used semi-structured interview to collect data which was analyzed using qualitative data analysis approach. The study found personal skills, i.e., computer, higher order thinking, language, and communication skills facilitate students' information search and use in higher learning. The study suggested that universities must help students to develop necessary skills that enable them to strategically search and use information in knowledge building process in higher learning.
\end{abstract}

\section{Keywords}

Information Skills, Information Behaviors, Higher Learning, Malaysia

\section{Introduction}

Seminal works by Marland (Marland, 1981), Irving (Irving, 1985) and Herring (Herring, 1996) in the United Kingdom defined information skills as a set of learning skills that assist students to use, transform, re-package, and communicate information. Presently information skills have been identified as pre-requisite skills for lifelong and higher learning (Bundy, 2004; Catts \& Lau, 2008). In particular, information skills are necessary to assist the transformation of students' role from information receivers to knowledge constructors, indicated by the transformation of higher learning approach from teacher-centered 
learning to student-centered learning. In the context of Malaysia, information skills programs have been introduced in public universities initially to transform students into knowledge workers (Edzan \& Mohd Saad, 2005; Mohd Saad \& Awang Ngah, 2002) who are characterized by their ability to "acquire, apply, synthesize and create knowledge” (Economic Planning Unit, 2001: p. 112). Later, the introduction of the Malaysian Qualification Framework (Malaysian Qualifications Agency, 2007) that called for student-centered learning in higher education has reinforced the implementation of information skills programs in Malaysian universities. Recently, the development of the Education Transformation Plan 2015-2025 for Higher Education (Ministry of Education Malaysia, 2015) further signifies the role of information skills in developing inquisitive and innovative minds, and generating knowledge to solve problems.

The purpose of the study is to explore the role of various personal skills in students' information search and use as experienced and perceived by university lecturers, librarians and students in the context of Malaysia. The study would lead to the identification of enablers that empower strategic information search and use in higher learning in Malaysia and other Asian countries. The findings would be beneficial to improve effective collaboration between classroom learning and academic libraries to develop necessary learning skills for students to strategically search and use information in knowledge building process in higher learning.

\section{Literature Review}

Literature has highlighted that students' application of information skills is influenced by multiple personal contexts. Among others, Neely (Neely, 2000) found that students' experience and exposure to library or other information environments influenced students' engagement in information-related behaviors and thinking. Gorman \& Dorner (Gorman \& Dorner, 2006), Grassian \& Kaplowitz (Grassian \& Kaplowitz, 2001), and Lantz \& Brage (Lantz \& Brage, 2006) also argued that students' daily tasks, needs, and interests also influence students' usage of information skills. Moreover, Kilic-Cakmak (Kilic-Cakmak, 2010) suggested that personal learning strategies, critical thinking and control belief contribute toward students' perceptions of their level of information skills. Most studies have investigated students' information skills using dual perspectives of lecturers-librarians (e.g., Boon, Johnston, \& Webber, 2007; Bruce, 1997) and single perspective of students (e.g., Lupton, 2003; Maybee, 2007). Hence, there is still a gap to understand students' information skills using multiple perspectives of university lecturers, librarians and students. In Malaysia, there are few studies that examined students' information skills in Malaysian higher education, (e.g., Abdullah, Ahmad Kassim, Mohd Saad, Tarmuchi, \& Aripin, 2006; Edzan, 2007; Karim, Shah, Ahmad, \& Lubis, 2014). However, most of these studies attempted to quantify students' information skills and correlated the information skills with students' demographic information such as academic programs and aca- 
demic achievement. While these findings might be helpful to describe students' level of information skills, they might be insufficient to explain the role of personal skills in empowering students' information search and use in higher learning.

\section{Methodology}

This study employed a qualitative research approach characterized by real and information rich cases, and flexible and emergent in the nature (Bogdan \& Biklen, 2007; Merriam, 2009). Qualitative research approach has been widely employed to investigate information skills in higher learning such as studies conducted by Karim (Karim, Shah, Khalid, Ahmad, \& Din, 2015), Maybee (Maybee, 2007), Bruce (Ministry of Education Malaysia, 2015) and Doyle (Doyle, 1992). This study was conducted in a Malaysian public university that offers student information skills programs and allows an entry for data collection process. Working closely with a few librarians in the university's academic library, the study selected five student information skills programs that involved teachers, librarians and students and interviewed lecturers, librarians and students involved in the programs. One professor, two associate professors and one senior lecturer from social science and pure science programs, as well as two young librarians and two senior librarians with management position were willing to participate in the study. All lecturers and librarians are Malay origins. Table 1 show profiles of 21 students participated in the study respectively. For the purpose of research ethics, the study used pseudonyms to protect the participants' privacy and confidentiality.

Specifically, the study conducted four individual and one paired semi-structured interviews with the librarians; five individual semi-structured interviews with the lecturers, and ten individual, four paired and one trio semi-structured interviews with 21 students. Data in the study was analyzed using Merriam's (Merriam, 2009) steps of analyzing qualitative data that suggest using the research purpose to guide the data analysis process. Using the steps, the study developed bucket, open and analytical coding that helps the study to construct a meaningful "classification system" (Merriam, 2009: p. 180) of personal skills that found by the study to empower students' information search and use. The classification system indicated patterns and regularities of major themes that appeared frequently across sources and cases. The study also employed Nvivo computer program to organize the data and the developed coding for easy storage and retrieval.

\section{Findings}

Four personal skills emerged in the study that enable students' information search and use in higher learning. As discussed below, the identified skills are computer, higher order thinking, language, and communication skills. 
Table 1. Profile of student participants.

\begin{tabular}{|c|c|c|c|c|c|c|}
\hline No. & Students & Gender & Ethnic & Age & Degree & Programs \\
\hline 1 & Cheng & Male & Chinese & $20-25$ & Bachelor & Pure science \\
\hline 2 & Feza & Female & Malay & $20-25$ & Bachelor & Pure science \\
\hline 3 & Fazil & Male & Malay & $20-25$ & Bachelor & Pure science \\
\hline 4 & Hani & Female & Malay & $20-25$ & Bachelor & Pure science \\
\hline 5 & Kan & Female & Indian & $20-25$ & Bachelor & Pure science \\
\hline 6 & Lily & Female & Malay & $20-25$ & Bachelor & Pure science \\
\hline 7 & Leng & Female & Chinese & $20-25$ & Bachelor & Pure science \\
\hline 8 & Razak & Male & Malay & $20-25$ & Bachelor & Pure science \\
\hline 9 & Amy & Female & Malay & $20-25$ & Bachelor & Social science \\
\hline 10 & Kam & Female & Malay & $20-25$ & Bachelor & Social science \\
\hline 11 & Kay & Female & Malay & $20-25$ & Bachelor & Social science \\
\hline 12 & Muz & Male & Malay & $20-25$ & Bachelor & Social science \\
\hline 13 & $\mathrm{Raz}$ & Male & Malay & $20-25$ & Bachelor & Social science \\
\hline 14 & Awatif & Female & Malay & $26-30$ & Master & Social science \\
\hline 15 & Joe & Male & Malay & $26-30$ & Master & Social science \\
\hline 16 & Karin & Female & Malay & $26-30$ & Master & Social science \\
\hline 17 & Wina & Female & Maly & $26-30$ & Master & Social science \\
\hline 18 & Jannah & Female & Malay & $36-40$ & Master & Social science \\
\hline 19 & Maya & Female & Malay & $26-30$ & Master & Social science \\
\hline 20 & Naim & Female & Malay & $30-35$ & Master & Social science \\
\hline 21 & Nori & Female & Malay & $36-40$ & Master & Social science \\
\hline
\end{tabular}

\subsection{Computers Skills}

Lecturers (Ana, Nora, Onn and Wani) considered that computer skills enable students to access and retrieve relevant and recent information available within online databases subscribed to by the university library and available on the Internet. Nora added that computer skills are useful for students to organize and cite information and its sources electronically during the writing of their understanding. Wani further viewed that a combination of critical thinking and computer skills help students to develop effective public artefacts such as PowerPoint presentation to communicate their understanding. Aware of the importance of computer skills in students' application of information skills, librarians said that they ran information skills programs that aim to assist students to acquire computer skills that aims to assist to search and retrieve online information sources, organize and cite the information sources electronically, and develop effective PowerPoint presentation.

Similarly, students experienced that computer skills have helped them to search online information from multiple sources easily and quickly. The stu- 
dents also communicated with classroom peers and experts in their field of learning through email, Skype and Yahoo Messenger. Moreover, the study found that lecturers' computer skills increase students' motivation to acquire computer skills. For example, final year undergraduate university students (Feza and Fazil) voluntarily joined an information skills program that exposed them to the use of Endnote program due to their thesis supervisor's knowledge and preference of the program. Another lecturer (Nora) supported the students' view by highlighting the importance of lecturers upgrading their computer skills in facilitating electronic and online information search and retrieval among students.

\subsection{Higher Order Thinking Skills}

Lecturers (Ana, Nora, Onn, Sam and Wani) noted that higher order thinking skills assist students to analyze and synthesize information independently from their lecturers. Specifically, the lecturers associated the skills with students' abilities to logically, critically, creatively, reflectively, and independently use or "digest" (Ana) information from multiple sources to develop, validate and articulate their understanding. Although teachers did not explicitly talk about higher order thinking skills during their classroom learning, they identified the application of the skills while grading public artefacts developed by students to showcase their understanding and the construction of the understanding, i.e., research proposals, literature reviews, and other term papers. A lecturer (Ana) found that the lack of higher order thinking skills among her undergraduate students often can be seen in their writing of research literature review and discussion. Another lecturer (Wani) added that students' lack of higher order thinking skills often led to their inability to learn independently from their lecturers which is the opposite of student-centered learning highlighted by the Malaysian Qualification Framework. Wani commented that that she needs to train her students to critically posing reflective questions that would help them to answer their own questions. On the same notes, librarians (Mia and Sal) found that students who consulted them on information searching and retrieving often do not think critically about their information needs prior conducting databases searching in the library as well as unable to evaluate information that are relevant to their research projects.

Final undergraduate students (Fazil, Feza, and Razak) and postgraduate students (Joe, Jannah, Naim and Wina) also agreed that higher order thinking skills help them to identify, extract, compare, contrast, and synthesize various ideas from multiple sources into their own understanding. The students also found that critical thinking skills help them to present and defend their understanding during classroom discussion. For example, a young postgraduate university student (Joe) associated critical thinking skills with students' ability to search and retrieve relevant information from multiple sources, while another young postgraduate student (Wina) identified the skills with students' ability to articulate their understanding using a rigid format of academic writing of reporting find- 
ings and referencing. Another mature postgraduate student (Jannah) associated information skills with students' ability to convincingly present and justify their knowledge and understandings during classroom discussions or question-and-answer sessions. On the other hand, the study also found that given an opportunity, young undergraduate students (Amy, Kay and Kam) are more inclined to skip the application critical thinking skills in their information search and use process by copying and claiming other persons' writing in the internet as they own. This observation is supported by lecturers (Wani and Onn) who viewed that there is a need for lecturers to monitor students' use of critical thinking skills during classroom learning using various types of learning assessment.

\subsection{Language Skills}

Lecturers and students thought that students' mastery of the language in which the disciplines of knowledge were developed and expanded would facilitated students' information search and use. For example, lecturers such as Nora and Wani considered that international students coming from non-English speaking countries would be able to articulate and present their understanding through classroom assignments, and research proposal and report if they master an acceptable standard for academic English speaking and writing. On the same note, postgraduate students (Joe and Naim) were able to search, read, analyze, and synthesize information from original, authentic as well as current information sources due to their mastery of English and Arabic languages, in which their knowledge discipline was developed respectively. On the contrary, second year undergraduate students (Amy, Kay and Kam) said that, because their English was not proficient, they faced difficulty in understanding information sources prescribed in their classroom reading materials which were available mostly in English. As a result, these students limit their usage of information sources to secondary information sources, such as personal blogs or translated books that were written in Malay language, to complete their classroom assignments.

\subsection{Communication Skills}

Participants were of the opinion that communication skills also facilitated students' application of information skills. A lecturer (Wani) said that communication skills enable students to articulate and share their understandings to members of classroom learning and knowledge discipline community-essential traits for graduates who compete in the job market. Similarly, a lecturer (Onn) pointed out that verbal communication skills assisted his undergraduate Chinese students to better share and reflect their understandings with him in comparison to his undergraduate Malay students who preferred to use body language. This situation limited the Malay students' writing and oral articulation and reflection of their understanding which are the most applied modes of communication in higher learning activities. Likewise, the university librarians (Azi and Sal) no- 
ticed that Malay undergraduate students often lacked confidence to communicate with librarians while they were in the library. Conversely, the librarians found that Chinese and international students were more assertive than Malays in seeking the librarians' help in conducting information search and retrieval. The findings suggested that communication skills were important to help students to better engage in all components of information skills while completing their classroom assignments.

Similarly, students viewed that communication skills were also important for lecturers and librarians. Due to time constraints during lectures, final year undergraduate students (Hani and Lili) preferred to discuss their ideas with lecturers outside the classroom only if the teachers were open in their communication, easily accessible to students and respectful of the students' ideas. Likewise, final year undergraduate students (Fazil and Feza) were also comfortable discussing their work with lecturers who did not look down on their ideas but reflected the ideas transparently and critically. One of the lecturers (Onn) also agreed that teachers who patronised and publicly embarrassed their students would destroy the students' motivation and talents, and thus disengage the students from searching and using information to validate their current understanding. Similarly, undergraduate students (Amy, Chan, Kay, Kam, and Razak) and a lecturer (Nora) experienced that librarians also needed to employ good communication skills while conducting information skills programs. The communication skills would increase interaction between librarians and students that would help the librarians to identify and address students' needs or knowledge gaps related to the process of information search and retrieval. For example, second year undergraduate students (Amy, Kam, and Kay) thought such interaction would help them to fulfill their information needs and stay focus throughout the programs.

\section{Discussion}

The study revealed that computer skills, higher order thinking skills, language skills and communication skills empower students to search and use information across classroom learning. Similarly, previous studies (e.g., Bundy, 2004; Marcum, 2002) suggested that information skills are made up of interrelated skills such as critical thinking, computer, library, and learning skills. Additionally, Bruce (Bruce, 1997) viewed that information literacy was underpinned by the use of information technology, library, and critical thinking skills. The literature also has widely discussed the relationship between computer skills and information skills. For example, Balas (Balas, 2006: p. 29) argued that "[c]omputer and information literacy go together like the old-fashioned horse and carriage". Specifically, computer skills influence the ways in which students search, access, store, retrieve, record, organize, use, create, and communicate information (Society of College National \& University Libraries, 1999). Due to its importance, the literature highlights computer skills as an enabler of information literacy (e.g., Association of College \& Research Libraries, 2000; Council of Australian 
University Librarians, 2001). Accordingly, a few researchers (e.g., Balas, 2006; Ashley, Jarman, Varga-Atkins, \& Hassan, 2012) urged librarians to assist students in becoming both computer- and information-literate, while recent literature (e.g., Isabel RodrÃ $\neg$ guez-de-Dios \& Juan-JosÃ@ Igartua, 2016; Rodrã-guez De Dios, Isabel \& van Oosten, Johanna \& Igartua, Juan Jos ̃̃॰, 2018) argued that both information and computer technology skills constitute an overarching digital skills.

However, Godwin (Isabel RodrÃ $\neg$ guez-de-Dios \& Juan-JosÃ@ Igartua, 2016) argued that being computer literate does not necessarily mean students will become information-literate. Although students in the information age are fluent in computer applications and technology, they lack the abilities to search, evaluate, analyze, and synthesize information and its sources in a critical and reflexive manner (Balas, 2006; Godwin, 2006; Beeson, 2006). Similarly, Hart (Hart, 2001) claimed that the knowledge construction process does not equate with computer fluency. The findings of the study showed that computer skills enable students to apply certain elements of information skills, (i.e., searching, retrieving, storing, creating, and communicating information and sources) that are underpinning by various applications and tools of information technology. Similar to the literature, the findings assert that information technology skills alone are not sufficient in helping students to evaluate, analyze, and transform the information and its sources which they have retrieved into personal understanding; they need higher order thinking skills in order to do that. The relationship between higher order thinking skills and information skills is also discussed in the literature. For examples, Albitz (Albitz, 2007) and Loertscher and Woolls (Loertscher \& Woolls, 1997) claimed that critical thinking is the 'end' for information skills, while the Association of College and Research Libraries (Association of College \& Research Libraries, 2000) and Bundy (Bundy, 2004) posited critical thinking as both the means and the end of information skills. Similarly, existing information skills standards for higher education students (e.g., Bundy, 2004; Society of College National \& University Libraries, 1999; Association of College \& Research Libraries, 2000) and recent information skills literature (e.g., Tewell, 2018; Chen, Sin, Theng, \& Lee, 2018; Downey, 2016; Bales, 2015) have outlined that critical thinking and approach should underpinned how information is used in any information-related behaviors and thinking.

Finally, the study found that computer skills and higher order thinking skills alone are insufficient to assist students to present, defend and negotiate the developed understanding; the students need language and communication skills to perform such tasks. The findings support the available literature that often associates information skills with language and communication skills such as by Catts and Lau (Catts \& Lau, 2008) that have argued that a combination of information, media, basic oral communication, and reasoning literacy could lead to the development and running of the knowledge society; a society driven by the creation, dissemination and use of information. The dynamic relationship 
between language and communication skills, and information skills is also highlighted by the Middle States Commission on Higher Education (Middle States Commission on Higher Education, 2003) that views an information creation, dissemination and usage in the knowledge society or learning community is sustained by its members' ability to communicate the understanding as intended using multiple forms; vocally (using voice), written (using printed or digital media such as books, magazines, websites or emails), visually (using logos, maps, charts or graphs) or non-verbally (using body language, gestures and the tone and pitch of voice). On the other hand, recent literature has argued (e.g. Isabel RodrÃ ᄀguez-de-Dios \& Juan-JosÃ@ Igartua, 2016; RodrÃ-guez De Dios, Isabel \& van Oosten, Johanna \& Igartua, Juan JosÃ $\odot, ~ 2018)$ that both information and communication skills constitute digital skills necessary for the digital natives of today.

\section{Conclusion}

The study showed that computer skills, higher order thinking skills, language skills and communication skills enable students' search and use across classroom learning. Unfortunately, the study found that not all students are well-equipped with these skills at the beginning of their university study. Some students took almost one whole semester or more before acquiring and using the skills; experiencing an unproductive learning process and low academic achievement in the first semester of their study. Accordingly, there is a need for higher education institutions to identify the gap of students' personal skills related to higher learning among fresh university students, and later design and develop special programs to assist the students' acquisition and use of these skills across classroom learning. By doing so, fresh undergraduate students are able to strategically search and use information in knowledge building process in higher learning and perform better early in their university life.

\section{Conflicts of Interest}

The authors declare no conflicts of interest regarding the publication of this paper.

\section{References}

Abdullah, S., Ahmad Kassim, N., Mohd Saad, M. S., Tarmuchi, N. R., \& Aripin, R. (2006). Developing Information Literacy Measures for Higher Education. In Proceedings of the Asia-Pacific Conference on Library \& Information Education \& Practice (pp. 219-228). Singapore: School of Communication \& Information, Nanyang Technological University. http://dlist.sir.arizona.edu/1384/01/31.Szarina_Abdullah_pp219-228_.pdf

Albitz, R. S. (2007). The What and Who of Information Literacy and Critical Thinking in Higher Education. Portal: Libraries and the Academy, 7, 97-109. https://doi.org/10.1353/pla.2007.0000

Ashley, J., Jarman, F., Varga-Atkins, T., \& Hassan, N. (2012). Learning Literacies through Collaborative Enquiry; Collaborative Enquiry through Learning Literacies. Journal of Information Literacy, 6, 50-71. 
Association of College \& Research Libraries (2000). Information Literacy Standards for Higher Education.

https://alair.ala.org/bitstream/handle/11213/7668/ACRL\%20Information\%20Literacy\% 20Competency $\% 20$ Standards $\% 20$ for $\% 20$ Higher\%20Education.pdf?sequence $=1$ \&isAllo wed $=\mathrm{y}$

Balas, J. L. (2006). Information Literacy and Technology-They Work Best when They Work Together. Computers in Libraries, 26, 26-29.

Bales, S. (2015). The Dialectic of Academic Librarianship: A Critical Approach. Sacramento, CA: Litwin Books.

Beeson, I. (2006). Judging Relevance: A Problem for e-Literacy. ITALICS, 5, 210-219. https://doi.org/10.11120/ital.2006.05040210

Bogdan, R. C., \& Biklen, S. K. (2007). Qualitative Research for Education: An Introduction to Theories and Methods. Boston, MA: Pearson Education, Inc.

Boon, S., Johnston, B., \& Webber, S. (2007). A Phenomenographic Study of English Faculty's Conceptions of Information Literacy. Journal of Documentation, 63, 204-228. https://doi.org/10.1108/00220410710737187

Bruce, C. (1997). The Seven Faces of Information Literacy. Adelaide, SA: Auslib Press.

Bundy, A. (Ed.). (2004). Australian and New Zealand Information Literacy Framework: Principles, Standards and Practice (2nd ed., pp. 7-8). Adelaide, SA: Australian and New Zealand Institute for Information Literacy.

Catts, R., \& Lau, J. (2008). Towards Information Literacy Indicators: Conceptual Framework Paper. Paris: UNESCO.

Chen, X., Sin, S.-C. J., Theng, Y.-L., \& Lee, C. S. (2018). Why Students Share Misinformation on Social Media: Motivation, Gender, and Study-Level Differences. The Journal of Academic Librarianship, 41, 583-592. https://doi.org/10.1016/j.acalib.2015.07.003

Council of Australian University Librarians (2001). Information Literacy Standards. http://ilp.anu.edu.au/Infolit_standards_2001.html

Downey, A. (2016). Critical Information Literacy: The State of the Field. Sacramento, CA: Litwin Books.

Doyle, C. S. (1992). Development of a Model of Information Literacy Outcomes Measures within National Education Goals of 1990. Unpublished Doctoral Dissertation, Arizona: Northern Arizona University.

Economic Planning Unit. (2001). Eighth Malaysian Plan 2001-2005. Putrajaya: Economic Planning Unit, Prime Minister's Department, Malaysia.

Edzan, N. N. (2007). Tracing Information Literacy of Computer Science Undergraduates: A Content Analysis of Students' Academic Exercise. Malaysian Journal of Library \& Information Science, 12, 97-109.

Edzan, N. N., \& Mohd Saad, M. S. (2005). NILA: A National Information Literacy Agenda for Malaysia. Malaysian Journal of Library \& Information Science, 10, 91-103.

Godwin, P. (2006). Information Literacy in the Age of Amateurs. ITALICS, 5, 268-287. https://doi.org/10.11120/ital.2006.05040268

Gorman, G. E., \& Dorner, D. G. (2006). Information Literacy Education in Asian Developing Countries: Cultural Factors in Affecting Curriculum Development and Programme Delivery. World Library and Information Congress: 72nd IFLA General Conference and Council, Seoul. http://www.ifla.org/IV/ifla72/papers/082-Gorman_Dorner-en.pdf

Grassian, E. S., \& Kaplowitz, J. R. (2001). Information Literacy Instruction: Theory and 
Practice. New York, NY: Neal-Schuman Publishers.

Hart, T. (2001). From Information to Transformation: Education for the Evolution of Consciousness. New York, NY: Peter Lang Publishing.

Herring, J. E. (1996). Teaching Information Skills in Schools. London, UK: Library Association Publishing.

Irving, A. (1985). Study and Information Skills across the Curriculum. London, UK: Heinemann Educational Books.

Karim, A. A., Shah, P. M., Ahmad, M., \& Lubis, M. A. (2014). Developing Information Skills Test for Malaysian Youth Students Using Rasch Analysis. International Education Studies, 7, 112-122. https://doi.org/10.5539/ies.v7n13p112

Karim, A., Shah, P., Khalid, F., Ahmad, M., \& Din, R. (2015). The Role of Personal Learning Orientations and Goals in Students' Application of Information Skills in Malaysia. Creative Education, 6, 2002-2012. https://doi.org/10.4236/ce.2015.618205

Kilic-Cakmak, E. (2010). Learning Strategies and Motivational Factors Predicting Information Literacy Self-Efficacy of E-Learners. Australasian Journal of Educational Technology, 26, 192-208. https://doi.org/10.14742/ajet.1090

Lantz, A., \& Brage, C. (2006). Towards a Learning Society-Exploring the Challenge of Applied Information Literacy through Reality-Based Scenarios. Innovation in Teaching and Learning Information and Computer Science, 5, 1-15.

http://www.ics.heacademy.ac.uk/italics/vol5-1/pdf/Lantz\&Brage\%20final.pdf https://doi.org/10.11120/ital.2006.05010003

Loertscher, D. V., \& Woolls, B. (1997). The Information Literacy Movement of the School Library Media Field: A Preliminary Summary of the Research. http://slisweb.sjsu.edu/courses/250.loertscher/modelloer.html

Lupton, M. (2003). Researching an Essay: Undergraduates' Way of Experiencing Information Literacy. Unpublished Master's Thesis, Canberra: Division of Communication and Education, University of Canberra.

Malaysian Qualifications Agency. (2007). Malaysian Qualifications Framework: Point of Reference and Joint Understanding of Higher Education Qualifications in Malaysia. http://www.mqa.gov.my/portalmqav3/document/mqf/MALAYSIAN\%20QUALIFICA TIONS\%20FRAMEWORK_2011.pdf

Marcum, J. W. (2002). Rethinking Information Literacy. Library Quarterly, 72, 27. https://doi.org/10.1086/603335

Marland, M. (Ed.). (1981). Information Skills in the Secondary Curriculum. London, UK: Methuen Educational.

Maybee, C. (2007). Understanding Our Student Learners: A Phenomenographic Study Revealing the Ways That Undergraduate Women at Mills College Understand Using Information. Reference Services Review, 35, 452-462.

https://doi.org/10.1108/00907320710774319

Merriam, S. B. (2009). Qualitative Research: A Guide to Design and Implementation. San Francisco, CA: Jossey-Bass.

Middle States Commission on Higher Education (2003). Developing Research \& Communication Skills: Guidelines for Information Literacy in the Curriculum. Philadelphia: Middle States Commission on Higher Education.

Ministry of Education Malaysia. (2015). Executive Summary: Malaysia Education Blueprint 2015-2025 (Higher Education). Putrajaya: Ministry of Education Malaysia.

Mohd Saad, M. S., \& Awang Ngah, Z. (2002). Information Literacy Programmes in Malaysian Public Universities: An Observation. 68th International Federation of Library 
Associations and Institution Annual Council and General Conference, Glasgow. http://www.ifla.org/IV/ifla68/papers/142-098e.pdf

Neely, T. Y. (2000). Aspects of Information Literacy: A Sociological and Psychological Study. Unpublished Doctoral Dissertation, Pittsburgh: University of Pittsburgh.

RodrÃ-guez De Dios, I., \& Juan-JosÃ, I. (2016). Skills of Digital Literacy to Address the Risks of Interactive Communication. Journal of Information Technology Research, 9, 54-64.

RodrÃ-guez De Dios, I., van Oosten, J., \& Juan-JosÃ, I. (2018). A Study of the Relationship between Parental Mediation and Adolescentsât ${ }^{m x}$ Digital Skills, Online Risks and Online Opportunities. Computers in Human Behavior 82.

https://doi.org/10.1016/j.chb.2018.01.012

Society of College National \& University Libraries (1999). Information Skills in Higher Education: A Sconul Position Paper.

https://www.sconul.ac.uk/sites/default/files/documents/Seven_pillars2.pdf

Tewell, E. (2018). The Practice and Promise of Critical Information Literacy: Academic Librarians' Involvement in Critical Library Instruction. College \& Research Libraries, 79, 10-34. https://doi.org/10.5860/crl.79.1.10 